\title{
Laporan Kasus Berbasis Bukti Perbandingan Ultrasonografi Paru dan Rontgen Dada sebagai Alat Bantu Diagnostik Pneumonia pada Anak
}

Yosilia Nursakina, Tartila, Evita Bermanshah Ifran

Departemen Ilmu Kesehatan Anak Fakultas Kedokteran Universitas Indonesia/RS. Dr. Cipto Mangunkusumo, Jakarta

Latar belakang. Pemeriksaan Rontgen dada seringkali dilakukan pada pasien anak dengan pneumonia. Akan tetapi, pemeriksaan Rontgen dada memiliki sejumlah kekurangan, seperti meningkatkan paparan radiasi ionisasi pada anak, memiliki jeda lama dalam mengambil dan memproses gambar, angka false positive tinggi, dan potensi variabilitas antarpengamat. Sejumlah literatur terbaru menunjukkan bahwa USG memiliki akurasi tinggi dalam mendiagnosis pneumonia dibandingkan Rontgen dada, serta dianggap ideal dalam pemeriksaan pada anak karena bebas radiasi dan portabel.

Tujuan. Membandingkan akurasi ultrasound paru dan Rontgen dada dalam menegakkan diagnosis pneumonia pada anak.

Metode. Penelusuran literatur secara terstruktur dilakukan melalui Pubmed ${ }^{\oplus}$, ScienceDirect ${ }^{\oplus}$, Proquest ${ }^{\oplus}$, Proquest ${ }^{\oplus}$, Scopus ${ }^{\oplus}$, ClinicalKey ${ }^{\oplus}$, dan $\mathrm{EBSCO}^{\circledast}$.

Hasil. Studi meta-analisis Balk dkk menunjukkan bahwa USG memiliki akurasi tinggi dalam mendiagnosis pneumonia pada anak dengan sensitivitas 0,96 vs 0,87 dan spesifisitas 0,95 vs 0,98. Sementara studi Xin dkk menunjukkan sensitivitas dan spesifisitas USG paru yang tinggi, yakni 0,93 dan 0,96 berturut-turut.

Kesimpulan. Kedua studi yang ditelaah menunjukkan kecenderungan sensitivitas yang lebih tinggi pada modalitas USG dibandingkan dengan Rontgen dada. Sari Pediatri 2021;22(5):318-24

Kata kunci: anak, pneumonia, ultrasonografi, rontgen dada

\section{Evidence Base Case Report Lung Ultrasound vs Chest X-ray for diagnosing pneumonia in Children}

Yosilia Nursakina, Tartila, Evita Bermanshah Ifran

Background. Chest radiographs are often performed in pediatric patients with pneumonia. However, chest radiographs have several disadvantages, such as exposure to ionizing radiation in children, long delay in taking and processing images, high false- positive rates, and potential inter-observer variability. Recent kinds of literature show that lung ultrasound has high accuracy in diagnosing pneumonia compared to chest $\mathrm{x}$-rays and is considered ideal in examining children because it is radiation-free and portable.

Objective. To compare the accuracy of pulmonary ultrasound and chest x-rays in diagnosing pneumonia in children

Methods. Systematic literature searching was done using Pubmed $^{\oplus}$, ScienceDirect ${ }^{\oplus}$, Proquest ${ }^{\oplus}$, Proquest ${ }^{\oplus}$, Scopus ${ }^{\oplus}$, ClinicalKey ${ }^{\oplus}$, dan EBSCO $^{\circ}$.

Result. The Balk et al meta-analysis showed that ultrasound had high accuracy in diagnosing pneumonia in children with a sensitivity of 0.96 vs. 0.87 and a specificity of 0.95 vs. 0.98 . Whereas, the study of Xin et al showed high sensitivity and specificity of lung ultrasound, ie 0.93 and 0.96 respectively.

Conclusion. The two studies examined showed a higher sensitivity trend in ultrasound modalities compared to chest X-rays. Sari Pediatri 2021;22(5):318-24

Keywords: pediatric, pneumonia, ultrasonography, chest x-ray

Alamat korespondensi: Tartila. Departemen Ilmu Kesehatan Anak Fakultas Kedokteran Universitas Indonesia/RS. Dr. Cipto Mangunkusumo, Jakarta. Email: dr.tartila@ gmail.com 
Yosilia Nursakina dkk: Perbandingan ultrasonografi paru dan rontgen dada sebagai alat bantu diagnostik pneumonia

$\mathrm{P}$ neumonia seringkali ditemukan pada kondisi gawat darurat. Data statistik menunjukkan period prevalence pneumonia di Indonesia berdasarkan diagnosis/gejala ialah sebesar angka kematian akibat pneumonia pada balita sebesar 1,19\%. ${ }^{1}$ Secara global, WHO menyatakan pneumonia merupakan penyebab paling utama kematian balita sehingga pemberian terapi secara adekuat dan cepat sangat penting. Infeksi saluran napas akut pada anak terbanyak disebabkan oleh virus dan diobati simptomatik. Pemeriksaan Rontgen dada diperlukan untuk menyingkirkan pneumonia bakterialis yang memerlukan terapi antibiotik. ${ }^{2}$

Diagnosis pneumonia ditegakkan secara klinis berdasarkan anamnesis dan pemeriksaan fisis. Hingga saat ini, pemeriksaan Rontgen dada masih merupakan alat bantu diagnostik standar pada pneumonia. Akan tetapi, penggunaan Rontgen dada juga meningkatkan paparan anak terhadap radiasi sehingga dapat memperbesar risiko kanker pasien tersebut di masa depan. Angka false positive yang tinggi juga berakibat pada penggunaan antibiotik yang berlebih dan pemberian terapi yang tidak tepat pada pasien anak dengan bronkospasme yang lebih membutuhkan bronkodilator. ${ }^{3}$ Pemeriksaan Rontgen dada juga memiliki jeda yang lama dalam mengambil dan memproses gambar, potensi variabilitas signifikan antar pengamat, serta tidak dapat mencakup $40 \%$ bagian paru yang tertutup oleh jantung, mediastinum, dan struktur subdiafragmatik. ${ }^{4}$

Salah satu alternatif modalitas radiografi yang dapat digunakan ialah ultrasonografi (USG). Dahulu, penggunaan USG paru dianggap tidak mampu laksana dikarenakan adanya tulang iga dan keberadaan udara pada paru normal. Akan tetapi, kemajuan teknologi, seperti penggunaan transduser fleksibel, dan analisis berbagai artefak USG yang berbeda antara paru normal dan patologis telah membantu mengatasi keterbatasan yang ada sebelumnya. Penggunaan USG dalam mendiagnosis pneumonia komunitas pertama kali diajukan pada tahun 1986. Sejak saat itu, terdapat banyak studi terkait penggunaan USG pada pneumonia dewasa dan anak. ${ }^{5}$ Sejumlah studi menunjukkan bahwa USG paru memiliki akurasi tinggi dalam penegakan diagnosis pneumonia pada pasien anak, bahkan lebih baik daripada CT scan. Modalitas ini dianggap ideal untuk diterapkan pada pasien anak karena portabel, praktis, bebas radiasi, dan dapat digunakan berulang kali. Identifikasi konsolidasi paru dengan atau tanpa bronkogram udara pada USG paru mempunyai sensitivitas dan spesifisitas tinggi adanya pneumonia bakterialis, sedangkan kelainan pada garis pleura dan ditemukannya garis b tidak spesifik untuk pneumonia bakterialis, gambaran ini dapat dijumpai juga pada pneumonia virus dan bronkiolitis. ${ }^{4}$

Dalam mencegah paparan radiasi yang berlebihan pada anak, diperlukan investigasi lebih lanjut terkait penggunaan teknik pencitraan alternatif yang tidak menggunakan radiasi ionisasi. Alat USG merupakan alat yang terdapat di IGD dan memiliki aksesibilitas tinggi, sehingga dapat menjadi alternatif dari Rontgen dada.

\section{Ilustrasi kasus}

Anak perempuan usia 8 bulan datang dengan keluhan sesak napas 1 hari sebelum masuk RS. Sesak napas muncul hilang timbul, tidak membaik dengan perubahan posisi, dan tidak disertai bibir membiru. Sesak disertai dengan demam yang naik turun, suhu menurun dengan Paracetamol, suhu puncak demam mencapai $38,8^{\circ} \mathrm{C}$. Sejak muncul sesak napas, pasien juga semakin sulit minum ataupun makan. Anak tampak lemas, buang air kecil semakin berkurang. Selain itu, pasien juga mengeluhkan batuk dan pilek sejak 1 minggu SMRS. Pada saat berada di IGD, pasien tampak sakit berat, kesadaran compos mentis, dan terdapat kegawatdaruratan respirasi berupa takipneu, saturasi oksigen $92 \%$, serta tanda-tanda, seperti retraksi dada, napas cuping hidung, dan head bobbing. Pada pemeriksaan fisik, didapatkan ronkhi basah halus pada kedua lapang paru. Pasien direncanakan pemeriksaan Rontgen dada, tetapi pemeriksaan tersebut butuh waktu yang lama, sedangkan pemeriksaan USG dapat dilakukan secara bedside, praktis, dan memberikan hasil dengan lebih cepat. Sebagai klinisi, perlu dilakukan penelusuran lebih lanjut mengenai penggunaan USG dibandingkan rontgen dada dalam mendiagnosis pneumonia pada anak.

\section{Metode penelusuran}

Pencarian literatur dilakukan pada enam basis data elektronik, yaitu Pubmed, Science Direct, Proquest, Scopus, Clinical Key, dan EBSCOHost untuk mencari penelitian yang relevan. Penelusuran dilakukan pada 
Yosilia Nursakina dkk: Perbandingan ultrasonografi paru dan rontgen dada sebagai alat bantu diagnostik pneumonia

Tabel 1. PICO

\begin{tabular}{|c|c|c|c|}
\hline Populasi (P) & Intervensi (I) & Pembanding $(\mathrm{C})$ & Hasil $(\mathrm{O})$ \\
\hline $\begin{array}{l}\text { Pasien anak dengan } \\
\text { pneumonia }\end{array}$ & Ultrasonografi paru & Rontgen dada & $\begin{array}{c}\text { Sensitivitas dan spesifisitas } \\
\text { diagnosis pneumonia }\end{array}$ \\
\hline \multicolumn{4}{|c|}{ Tabel 2. Hasil penelusuran kepustakaan } \\
\hline Database & Metode penelusuran & $\begin{array}{l}\text { Jumlah artikel yang } \\
\text { didapatkan }\end{array}$ & Artikel yang relevan \\
\hline Pubmed & (pediatric OR child & 12 & 2 \\
\hline ScienceDirect & OR children) $\quad A N D$ & 1 & 1 \\
\hline ProQuest & (pneumonia) & 16 & 2 \\
\hline EBSCO & (ultrasound $\quad O R$ & 38 & 7 \\
\hline ClinicalKey & ultrasonography) $A N D$ & 13 & 1 \\
\hline Scopus & $\begin{array}{l}\text { (chest } x \text {-ray }) \quad A N D \\
\text { (sensitivity } A N D \text { specificity) }\end{array}$ & 28 & 4 \\
\hline
\end{tabular}

tanggal 4 Februari 2019 dengan menggunakan kata kunci, antara lain "pediatric", "ultrasound", "chest x-ray", dan "sensitivity specificity" dengan beberapa kata yang serupa atau memiliki makna yang sama. Seluruh kata kunci dikombinasikan dengan Boolean operators. Literatur yang muncul pada saat penelusuran kemudian disesuaikan dengan kriteria inklusi yang meliputi: 1) berbahasa Inggris; 2) berupa meta-analisis atau systematic review; 3) relevan dengan pertanyaan klinis; dan 4) dipublikasi dalam 3 tahun terakhir. Kriteria eksklusi meliputi: 1) desain studi kasus kontrol atau potong lintang, 2) tidak tersedia dalam bentuk full text ataupun open access; dan 3) tidak dilakukan pada pasien anak-anak.

Berdasarkan penelusuran melalui Pubmed $\AA$, terdapat 2 artikel yang sesuai kriteria dari total 12 artikel yang ditemukan. Sementara itu, berdasarkan penelusuran melalui Proquest ${ }^{\circledR}$ terdapat 2 artikel yang sesuai dari 16 artikel yang ditemukan. Selain itu, dari EBSCO juga didapatkan 7 artikel dari total 38 artikel yang ditemukan. Pada penelusuran melalui ScienceDirect ${ }^{\circledR}$, ditemukan 1 artikel yang sesuai, dari ClinicalKey didapatkan 1 dari 13 artikel, dan melalui Scopus terdapat 4 dari 28 artikel. Tujuh belas artikel tersebut kemudian dilakukan filtering double, skrining abstrak, seleksi jenis studi, dan pencarian full text sehingga diketahui bahwa terdapat 2 artikel yang dapat digunakan dalam tinjauan kasus berbasis bukti dengan topik ini.

\section{Hasil penelusuran}

Studi meta-analisis: Lung ultrasound compared to chest $X$-ray for diagnosis of pediatric pneumonia: a metaanalysis (Level of evidence I)

Balk $\mathrm{dkk}^{4}$ melakukan systematic-review-metaanalysis yang bertujuan untuk melihat ketepatan diagnosis pneumonia pada anak dengan mengambil data sensitivitas, spesifisitas, positive predictive value, dan negative predictive value dari Rontgen dada dan USG. Pencarian literatur dilakukan secara sistematis melalui PubMed, EMBASE, dan Web of Science sampai Agustus 2017 yang difokuskan untuk artikel yang membahas mengenai pneumonia, USG paru, dan populasi anak. Subjek yang dilibatkan dalam studi ini meliputi pasien anak yang curiga pneumonia, dilakukan USG dan Rontgen dada, dan memiliki baku emas diagnosis klinis oleh dokter anak. Artikel yang hanya berupa abstrak dieksklusi. Referensi standar yang digunakan jelas dan seragam, yakni diagnosis klinis oleh ahli dokter anak. Hasil dari studi ini menunjukkan bahwa USG memiliki sensitivitas yang lebih tinggi daripada rontgen dada $(0,96$ vs 0,87$)$. Spesifisitas USG juga tidak jauh berbeda dengan rontgen dada $(0,95$ vs $0,98)$. Walaupun demikian, terdapat heterogenisitas pada literatur terkait penemuan pada USG paru terkait konsolidasi paru dan air/fluid bronchogram.

Studi meta-analisis: Is Lung Ultrasound Useful for Diagnosing Pneumonia in Children? A meta-analysis and systematic review (Level of evidence I) 
Kata pencarian

(pediatric OR children) AND (pneumonia) AND (ultrasound OR ultrasonography) AND (chest x-ray)

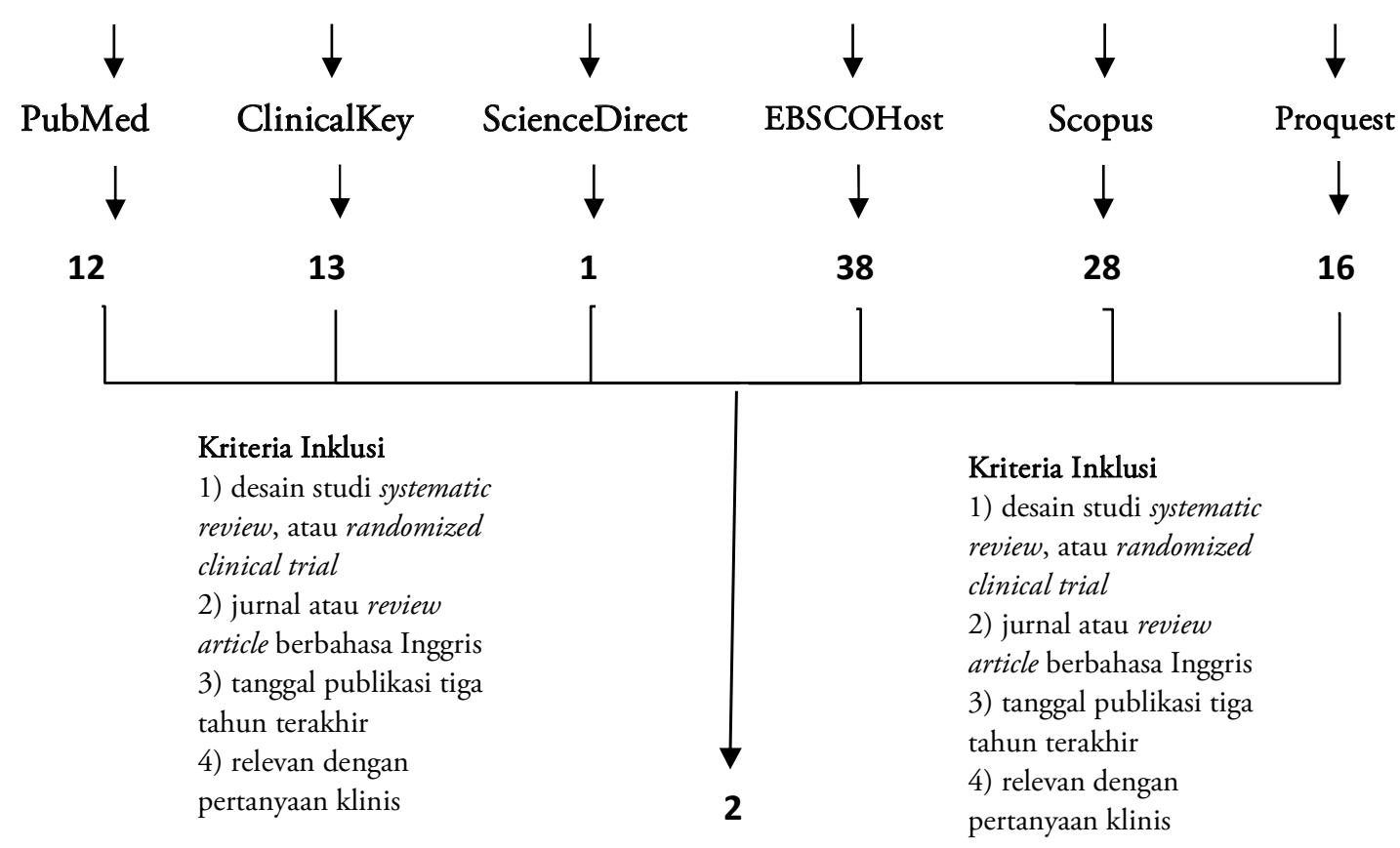

Gambar 1. Alur pemilihan literatur

Xin $\mathrm{dkk}^{8}$ menganalisis kegunaan USG dalam mendiagnosis pneumonia pada anak. Peneliti melakukan pencariaan sistematis melalui PubMed, Elsevier's Science Direct, Springer, dan pencarian manual hingga 31 Maret 2017. Kriteria inklusi dari meta-analisis ini ialah: 1) studi tersebut menilai efek USG paru dalam mendiagnosis pneumonia pada anak; 2) kriteria diagnosis pneumonia merupakan kombinasi data klinis, hasil laboratorium, dan pencitraan toraks melalui radiografi dada atau CT scan; 3) studi tersebut menyediakan data true-postive, false-positive, false-negative, dan true-negative; dan 4) studi tersebut melibatkan setidaknya 30 pasien yang berusia kurang dari 18 tahun. Setiap studi dinilai oleh dua orang investigator melalui QUADAS-2. Referensi uji standar yang digunakan ialah tanda klinis dan radiografi dada. Interpretasi USG paru juga tidak terpengaruh oleh temuan pada pemeriksaan fisik karena dilakukan blinding terlebih dahulu. Studi ini menunjukkan bahwa USG memiliki sensitivitas dan spesifisitas yang tinggi, yakni 0,93 dan 0,96 berturut-turut.

\section{Pembahasan}

Sejumlah studi telah membuktikan akurasi USG dalam mendiagnosis pneumonia. Analisis oleh Pereda $\mathrm{dkk}^{6}$ menunjukkan bahwa USG paru memiliki sensitivitas 96\% (95\% CI, 94-97\%), spesifisitas 93\% (95\% CI, 9096\%), nilai PLR 15,3 (95\% CI, 6,6-35,3), dan NLR 0,06 (95\% CI, 0,03-0,11). Tingginya sensitivitas dan spesifisitas USG pada sejumlah studi yang ada dapat disebabkan oleh proses patologis dari pneumonia itu sendiri. Ketika terjadi proses patologis pada paru, terjadi penggantian udara dengan substansi yang memiliki densitas lebih tinggi (cairan, pus, sekresi) sehingga mencapai permukaan pleura. Proses inilah yang dapat divisualisasi melalui USG sebagai konsolidasi. Opasitas pada konsolidasi paru memiliki densitas setara cairan, memiliki batas reguler/ireguler, dan memiliki bronkogram udara. Pada pemeriksaan USG, area konsolidasi tersebut dapat terlihat jika terdapat kontak dengan permukaan pleura. Konsolidasi pada USG terlihat sebagai lesi hipoekoik, ill-defined areas, 
Tabel 3. Rangkuman telaah kritis

\begin{tabular}{|c|c|c|}
\hline $\begin{array}{l}\text { Artikel } \\
\text { Desain penelitian } \\
\text { Level of evidence }\end{array}$ & $\begin{array}{l}\text { Balk dkk (2018) } \\
\text { Meta-analisis } \\
1\end{array}$ & $\begin{array}{l}\text { Xin dkk (2017) } \\
\text { Meta-analisis } \\
1\end{array}$ \\
\hline $\begin{array}{lll}\text { PICO } & & \\
- & \text { P } & \text { : Pasier } \\
- & \text { I }: \text { Ultra } \\
- & \text { C }: \text { Ront } \\
- & \text { O }: \text { Sensi }\end{array}$ & $\begin{array}{l}\text { nak dengan pneumonia } \\
\text { nografi paru } \\
\text { n dada } \\
\text { iitas dan spesifistas diagnosis pneumonia }\end{array}$ & \\
\hline Validitas & $\begin{array}{l}\text { Representative spectrum of patients } \\
\text { Terdapat } 12 \text { literatur yang dilibatkan dalam meta- } \\
\text { analisis ini. Seluruh studi merekrut pasien curiga } \\
\text { pneumonia berusia di bawah } 18 \text { tahun dengan } \\
\text { rata-rata usia berkisar antara 2,2-6,1 tahun. Sebagian } \\
\text { besar studi dilakukan di Eropa. Hanya satu studi yang } \\
\text { dilakukan di Asia, yakni negara India. Jumlah pasien } \\
\text { yang dilibatkan dalam literatur tersebut berkisar antara } \\
\text { 69-1519 orang. } \\
\text { Reference standard: } \\
\text { Referensi standar yang digunakan jelas dan seragam, } \\
\text { yakni diagnosis klinis oleh ahli dokter anak. } \\
\text { Blind comparison to gold standard } \\
\text { Pemeriksaan USG paru dilakukan blinding. } \\
\text { Seluruh studi yang dilibatkan dalam meta-analisis ini } \\
\text { menggunakan metode blinding untuk mencegah bias } \\
\text { dari operator USG paru. } \\
\text { Kesimpulan: sahih (valid) }\end{array}$ & $\begin{array}{l}\frac{\text { Representative spectrum of patients }}{\text { Terdapat } 8 \text { literatur yang dilibatkan dalam }} \\
\text { meta-analisis ini. Seluruh studi merekrut } \\
\text { setidaknya } 30 \text { pasien curiga pneumonia } \\
\text { dengan usia di bawah } 18 \text { tahun. } \\
\text { Reference standard: } \\
\text { Uji standar yang digunakan ialah tanda } \\
\text { klinis pneumonia dan radiografi dada. } \\
\text { Blind comparison to gold standard: } \\
\text { Seluruh literatur yang dibahas dalam } \\
\text { studi meta-analisis ini dilakukan blinding } \\
\text { terhadap pemeriksaan fisik. } \\
\text { Kesimpulan: sahih (valid) }\end{array}$ \\
\hline Importance & $\begin{array}{l}\text { Sensitivitas : } 0,96 \\
\text { Spesifisitas : } 0,95 \\
\text { Positive predictive value }: 0,99 \\
\text { Negative predictive value }: 0,86 \\
\text { Prevalensi : } 0,79 \\
\text { Likelihood ratio }+: 20,3 \\
\text { Likelihood ratio }-: 0,05 \\
\text { Post-test probability }+: 0,96 \\
\text { Post-test probability }-: 0,14\end{array}$ & $\begin{array}{l}\text { Sensitivitas : } 0,93 \\
\text { Spesifisitas : } 0,96 \\
\text { Positive predictive value : } 0,97 \\
\text { Negative predictive value }: 0,93 \\
\text { Prevalensi : } 0,46 \\
\text { Likelihood ratio }+: 25,8 \\
\text { Likelihood ratio }-: 0,07 \\
\text { Post-test probability }+: 0,96 \\
\text { Post-test probability - : } 0,07\end{array}$ \\
\hline Applicability & $\begin{array}{l}\text { Methods permit replication: } \\
\text { Metode penelitian menjelaskan uji diagnostik secara } \\
\text { rinci untuk diaplikasikan pada populasi. }\end{array}$ & $\begin{array}{l}\text { Methods permit replication: } \\
\text { Metode penelitian menjelaskan uji } \\
\text { diagnostik secara rinci untuk diaplikasikan } \\
\text { pada populasi. } \\
\text { Kesimpulan: dapat diaplikasi (applicable) }\end{array}$ \\
\hline
\end{tabular}

dengan bronkogram udara dan tervaskularisasi pada Doppler USG. Studi Lichtenstein dkk, menunjukkan 98,5\% pneumonia pada orang dewasa memiliki kontak dengan pleura. Pada pasien anak, karakteristik dinding dada yang lebih tipis dan volume paru yang lebih kecil dapat memperbesar kemungkinan kontak dengan pleura dan meningkatkan kualitas USG dalam mendiagnosis pneumonia pada anak. ${ }^{7}$

Di satu sisi, Rontgen dada memiliki sejumlah kekurangan, seperti positioning yang salah dan ekspansi 
paru yang tidak adekuat pada saat inspirasi dapat memberikan pengaruh besar pada hasil Rontgen dada. Walaupun demikian, terdapat lima daerah konsolidasi yang hanya dapat terdeteksi pada rontgen dada, dua di antaranya terdapat pada regio perihilar dan tiga lainnya pada region infrahilar. Hal ini dapat disebabkan oleh konsolidasi region perihilar yang tidak mencapai permukaan pleura sehingga tidak terlihat pada USG. Selain itu, terdapat pula potensi kesalahan pada regio infrahilar kiri. Hal ini dikarenakan oleh bayangan jantung yang berpotensi menimbulkan anomali akibat interpretasi yang berlebihan. ${ }^{2}$

Teknik penggunaan USG paru pada anak ialah anak diposisikan secara lateral decubitus atau posisi berdiri, sehingga terlihat area posterior dan lateral. Probe USG yang digunakan umumnya adalah tipe konveks dengan frekuensi $5-12 \mathrm{MHz}$ pada linear probe, 3,5-5 MHz pada convex probe, dan 5-8 pada microconvex. Dalam proses pemeriksaaan, hemitoraks dibagi menjadi enam segmen: anterior (parasternal hingga garis aksilaris anterior), lateral (anterior hingga garis aksillaris posterior), dan posterior (garis aksillaris posterior hingga paravertebral), masing-masing segmen dibagi menjadi dua yakni inferior dan superior. ${ }^{4}$

Pada pasien pneumonia, dapat ditemukan konsolidasi paru, bronkogram udara positif, garis pleural abnormal, dan efusi pleura. Secara sonografi, pneumonia dapat diidentifikasi sebagai lesi subpleural, nonhomogen, area hipoekogenik, dan/atau daerah seperti hepar dengan batas ireguler dan bronkogram udara positif. Gejala-gejala tersebut memiliki positive predictive value $97 \%$. Temuan pada USG tidak berbeda antara anak dan dewasa. ${ }^{8}$

Dalam studi Balk dkk, ${ }^{4}$ terdapat 1 studi yang mendiagnosis pneumonia berdasarkan abnormalitas garis pleura, 4 studi mendiagnosis berdasarkan garis-b fokal, dan 1 studi mendiagnosis berdasarkan efusi pleura. Walaupun demikian, terdapat sejumlah kasus dimana beberapa temuan didapatkan pada pasien. Secara garis besar, abnormalitas garis pleural dan garis-b fokal disertai konsolidasi dapat teridentifikasi pada pasien-pasien tersebut. Konsolidasi yang ditemukan tidak dispesifikasi, tetapi salah satu studi menyebutkan bahwa konsolidasi terkecil berukuran $6 \mathrm{~mm}$. Studi lainnya menemukan konsolidasi berukuran 13 subsentimeter. Konsolidasi yang ditemukan berukuran sangat kecil sehingga seluruhnya tidak terdeteksi pada saat dilakukan Rontgen dada. ${ }^{4}$ Walaupun USG paru dapat menunjukkan berbagai diagnosis banding dari penyakit paru, terdapat potensi munculnya artefak dan lesi subpleural. ${ }^{8}$

Studi yang dilakukan oleh Balk $\mathrm{dkk}^{4}$ menunjukkan bahwa sensitivitas USG paru lebih tinggi daripada Rontgen dada dalam mendiagnosis pneumonia pada anak $(0,96$ vs 0,87$)$. Walaupun memiliki sensitivitas yang lebih tinggi secara signifikan, angka spesifisitas $(0,95$ vs 0,98$)$ dan PPV $(0,99$ vs 0,99$)$ hampir setara antara USG paru dan Rontgen dada. Diperlukan penelitian lebih lanjut untuk mengevaluasi kemampuan diagnosis USG paru tanpa inklusi Rontgen dada sebagai standar referensi. Selain itu, dibutuhkan pula lebih banyak data terkait penemuan USG paru pada pneumonia pediatrik, seperti konsolidasi subsentimeter, abnormalitas garis pleura, dan garis-b konfluen fokal terisolasi. ${ }^{4}$

Studi yang dilakukan oleh $\mathrm{Xin} \mathrm{dkk}^{8}$ menunjukkan bahwa USG paru dapat menjadi modalitas pencitraan yang sangat baik dan dapat melengkapi radiografi dada dan pemeriksaan fisik dalam mendiagnosis dan mengawasi kasus pneumonia pada anak. Pemeriksaan USG paru memiliki kelebihan terutama karena paparan ionisasi terhadap pasien minim. Meta-analisis ini menunjukkan bahwa sensitivitas dan spesifisitas USG paru tinggi, yakni 0,93 dan 0,96 secara berturut-turut. Semakin tinggi sensitivitas dan spesifisitas suatu uji diagnostik, maka semakin efektif dan semakin akurat uji diagnostik tersebut dalam menegakkan diagnosis suatu penyakit. Walaupun demikian, kesimpulan ini hanya berdasarkan delapan studi yang sesuai dengan kriteria inklusi peneliti. Diperlukan penelitian dengan desain yang baik, multicenter, dan berskala besar untuk melakukan validasi terhadap kesimpulan dari studi ini dan mengevaluasi performa USG paru lebih lanjut dalam mendiagnosis pneumonia pada anak. ${ }^{8}$

Dengan angka negative predictive value yang rendah, USG berpotensi menggantikan Rontgen dada untuk mengeksklusi konsolidasi paru pada anak sehingga mengurangi paparan radiasi pada populasi tersebut. $^{2}$

\section{Kesimpulan}

Kedua studi yang ditelaah menunjukkan tren sensitivitas yang lebih tinggi pada modalitas USG dibandingkan dengan Rontgen dada. Aksesibilitas USG tinggi dan durasi penggunaan cepat sehingga dapat membantu 
pemeriksaan radiologis pada kondisi gawat darurat. Hal tersebut dapat menjadi solusi untuk menghemat biaya dalam penegakan diagnosis dan perencanaan tatalaksana pneumonia anak pada pelayanan kesehatan dengan fasilitas terbatas. Diperlukan penelitian terkait pada pasien di populasi Indonesia, serta penetapan pedoman lebih lanjut mengenai temuan USG yang khas pada pneumonia anak agar dapat menjadi acuan dalam ilmu kesehatan anak di masa depan.

\section{Daftar pustaka}

1. Kementerian Kesehatan RI. Profil kesehatan Indonesia Tahun 2013. Jakarta: Kementerian Kesehatan RI; 2014.

2. Claes AS, Clapuyt C, Menten R, Michoux N, Dumitriu D. Performance of chest ultrasound in pediatric pneumonia. Eur J Radiol 2017;88:82-7.

3. Ellington LE, Gilman RH, Chavez MA, dkk. Lung ultrasound as a diagnostic tool for radiographically-confirmed pneumonia in low resource settings. Respir Med 2017;128:57-64.

4. Balk DS, Lee C, Schafer J, dkk. Lung ultrasound compared to chest X-ray for diagnosis of pediatric pneumonia: a metaanalysis. Pediatric Pulmonology 2018;1-10. doi: https://doi. org/ 10.1002/ppul24020.

5. Boursiani C, Tsolia M, Kooumanidou C, dkk. Lung ultrasound as first-line examination for the diagnosis of community-acquired pneumonia in children. Pediatr Emerg Care 2017;33:62-6.

6. Pereda MA, Chavez MA, Hooper-Miele CC, dkk. Lung ultrasound for the diagnosis of pneumonia in children: a metaanalysis. William Checkley Pediatrics 2015;135:714-22. doi: 10.1542/peds.2014-2833

7. Lichtenstein D, Lascols N, Mezière G, Gepner A. Ultrasound diagnosis of alveolar consolidation in the critically ill. Intensive Care Med 2004;30: 276-281.

8. Xin $\mathrm{H}, \mathrm{Li} \mathrm{J}, \mathrm{Hu} \mathrm{HY}$. Is lung ultrasound useful for diagnosing pneumonia in children? A meta-analysis and systematic review. Ultrasound Q 2018;34:3-810. doi: 10.1097/ RUQ.0000000000000330. 